PENGUATAN

KAPASITAS

KETERAMPILAN

AKUNTANSI \section{BERBASIS SAK-ETAP}

Mochammad llyas Junjunan*, Ashari Lintang Yudhanti, Binti Shofiatul Jannah, Ratna Anggraini Aripratiwi, Nufaisa, Ajeng Tita Nawangsari

Program Studi Akuntansi, Universitas Islam Negeri Sunan Ampel Surabaya

\begin{abstract}
Abstrak
Pengguna lulusan akuntansi dari perguruan tinggi maupun sekolah kejuruan menuntut standar kapasitas kompetensi yang tinggi di era revolusi industri. Profesi akuntansi dirasakan masih cukup bertahan di tengah persaingan teknologi informasi yang semakin cepat berkembang apabila mempunyai kompetensi dan keterampilan khsusus yang dapat menjadi pembeda dengan sumber daya lainnya. Kegiatan pengabdian kepada masyarakat ini bertujuan untuk meningkatkan kapasistas keterampilan akuntansi berbasis SAK-ETAP bagi peserta didik SMK Antartika 2, Sidoarjo. Kegiatan pengabdian dilakukan secara bertahap meliputi perencanaan, pelaksanaan, dan evaluasi \& monitoring tentang peningkatan keterampilan akuntansi berbasis SAK-ETAP. Hasil pelatihan kegiatan menunujukkan bahwa adanya pengabdian pendampingan yang dilakukan oleh tim dosen akuntansi UIN Sunan Ampel Surabaya, secara signfikan meningkatkan pemahaman dan keterampilan peserta didik tentang akuntansi berbasis SAK-ETAP. Tingkat kepuasan mencapai $83 \%$ dari seluruh peserta yang telah mengikuti kegiatan pengabdian masyarakat ini.
\end{abstract}

Kata Kunci: Kapasitas; Keterampilan Akuntansi; Laporan Keuangan; Pelatihan; SAK-ETAP

\begin{abstract}
Users of accounting graduates from universities and vocational schools demand a high standard of competency capacity in the industrial revolution era. The accounting profession can still survive in the midst of increasingly rapidly developing information technology competition if it has unique competencies and skills that can differentiate it from other resources. This community service activity aims to increase the capacity of SAK-ETAP-based accounting skills for students of SMK Antarctica 2, Sidoarjo. Service activities are carried out in stages, including planning, implementation, and evaluation \& monitoring of improving SAK-ETAP-based accounting skills. The training activities show that the mentoring service carried out by the accounting lecturer team at UIN Sunan Ampel Surabaya significantly improves students' understanding and skills about accounting based on SAK-ETAP. The level of satisfaction reached $83 \%$ of all participants who had participated in this community service activity.
\end{abstract}

Keywords: Capacity; Accounting Skill; Financial Statements, Training; SAK-ETAP

\section{*Corresponding author \\ Mochammad llyas Junjunan \\ Email:mij@uinsby.ac.id}

(C) 2022 Some rights reserved

\section{PENDAHULUAN}

Era milenial menuntut berbagai percepatan pengembangan di beberapa sektor, terutama pada sumber daya manusia (Purnama et al., 2019). Saat ini dunia usaha dan dunia industri mencari sumber daya yang tidak hanya sekedar berkompeten di bidangnya, melainkan sumber daya tersebut dituntut dapat menjadi problem solver pada berbagai persoalan yang ada di lingkungan kerja (Anggapraja, 2016). Senada dengan kebutuhan sumber daya yang unggul, pekerjaan di era disrupsi saat ini menjadi salah satu tantangan bagi profesi. Salah satunya adalah seorang akuntan (Mahardika, 2020).

Isu revolusi industri menyebabkan kepanikan tertentu bagi seorang akuntan, dimana akuntan harus bersaing dengan teknologi yang dengan mudah beradaptasi dan berkembang secara periodik (Zaitul et al., 2020). Hal tersebut menjadi kekhawatiran bagi manajemen atau pimpinan perusahaan untuk mendapatkan seorang akuntan yang profesional dan adaptif (Syahril \& Andini, 2017). Bekerja dengan tim, dan bekerja dibawah tekanan 
tentu tidak mudah jika lulusan akuntansi dari perguruan tinggi maupun sekolah kejuruan tidak dipersiapkan sebaik mungkin.

SMK Antartika 2 Sidoarjo, yang memiliki jumlah Iulusan paling banyak di bidang akuntansi merasakan kegelisahan hal tersebut. Sehingga SMK Antartika 2 Sidoarjo membutuhkan dukungan fasilitator dan tambahan suplemen dari berbagai pihak yang dapat mengatasi persoalan tersebut. Salah satu upaya untuk mempersiapkan peserta didiknya memiliki daya saing yang unggul dan kompeten di dunia kerja adalah dengan mengadakan pelatihan peningkatan kompetensi yang diperuntukkan bagi siswa kelas XII SMK Antartika 2 Sidoarjo. Pelatihan peningkatan kompetensi tersebut merupakan bentuk perhatian dan kepedulian terhadap peserta didiknya, agar saat lulus tidak kehilangan arah, dan mengerti harus kemana tujuannya setelah Iulus, apakah siswa tersebut ingin melanjutkan studi ke perguruan tinggi, berwirausaha atau ingin langsung bekerja.

Sejalan dengan pengabdian masyarakat program studi akuntansi UIN Sunan Ampel Surabaya, SMK Antartika 2 Sidoarjo bekerja sama dengan tim dosen akuntansi UIN Sunan Ampel Surabaya untuk menyelaraskan tujuan bersama yang akan menghasilkan lulusan akuntansi di perguruan tinggi maupun di kejuruan yang siap menghadapi dunia kerja dengan berbagai tantangan yang dihadapi (Lukman \& Juniati, 2017).

Berbagai program kerjasama tersebut salah satunya adalah penguatan kapasitas keterampilan akuntansi berbasis standar akuntansi keuangan entitas tanpa akuntabilitas publik (SAK-ETAP). Program pengabdian masyarakat oleh tim dosen (instruktur) akuntansi UIN Sunan Ampel Surabaya fokus pada pendampingan peserta didik (siswa-siswi) SMK Antartika 2 Sidoarjo kelas 12 dalam rangka menyiapkan dan mematangkan skill akuntansi menghasilkan laporan keuangan handal dan relevan (Junjunan et al., 2020; Nugraheni et al., 2020) yang digunakan pada dunia usaha dan industri.

\section{METODE PELAKSANAAN}

Kegiatan pengabdian ini dilakukan melalui beberapa tahapan diantaranya adalah perencanaan, pelaksanaan, dan evaluasi.

\section{Tahap Perencanaan}

Kegiatan perencanaan diawali dengan adanya kesepahaman antara program studi akuntansi Universitas Islam Negeri Sunan Ampel, Surabaya dengan SMK Antartika 2 Sidoarjo. Kesepahaman tersebut berupa kerjasama dalam rangka menguatkan keterampilan akuntansi berbasis SAK-ETAP siswasiswi kelas XII SMK Antartika 2 Sidoarjo dalam menyambut dunia kerja pasca kelulusan. Alasan menggunakan siswa-siswi kelas XII dipilih sebagai responden dengan beberapa pertimbangan. Pertama, siswa-siswi kelas XII telah siap untuk memasuki dunia kerja. Kedua, mereka telah mendapatkan mata pelajaran akuntansi di tahun-tahun sebelumnya. Kegelisahan SMK Antartika 2 Sidoarjo ditangkap oleh tim dosen program studi akuntansi dengan memberikan berbagai desain dan konsep pelatihan penguatan keterampilan akuntansi berbasis SAKETAP.

Materi aplikatif yang disusun secara sistematis berdasarkan kasus terbaru disiapkan oleh tim dosen akuntansi UIN Sunan Ampel Surabaya berupa modul pelatihan akuntansi. Selain itu, tim dosen yang nanti akan menjadi instruktur selama proses pelatihan menyiapkan pretest dan posttest dalam rangka untuk mengukur tingkat keberhasilan pelatihan (Bahfiarti et al., 2020).

\section{Tahap Pelaksanaan}

Pelaksanaan dilakukan selama 3 (tiga) hari di SMK Antartika 2, Sidoarjo dengan melibatkan tim dosen (instruktur) akuntansi UIN Sunan Ampel Surabaya. Teknis pelaksanaan dibagi menjadi dua bagian (Rosyadi et al., 2021), pertama instruktur memberikan pretest kepada peserta, dan dilanjutkan dengan ada diskusi materi teori (Gambar 1), kemudian praktik pemecahan kasus akuntansi di bidang jasa, dagang, maupun manufaktur (Junjunan et al., 2021) selama dua hari.

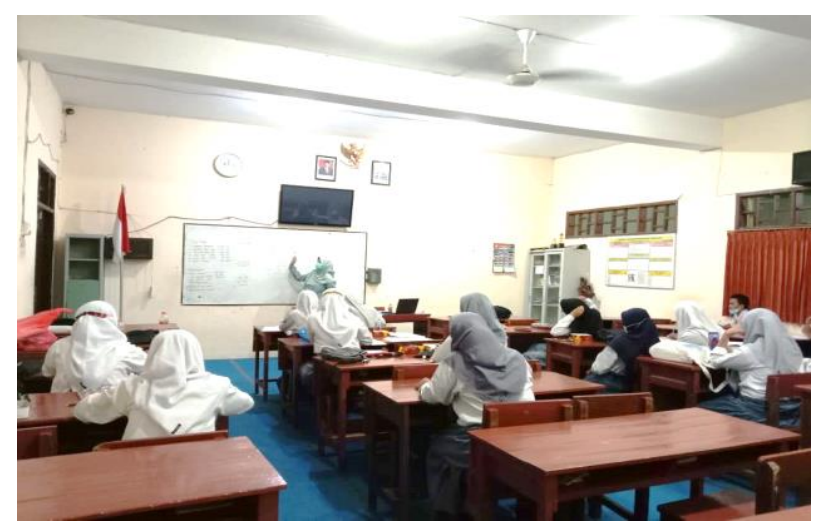

Gambar 1. Penjelasan materi oleh Instruktur (Dosen) Akuntansi UIN Sunan Ampel Surabaya

Bagian kedua adalah ujian yg diberikan berdasarkan modul yang sudah dibagikan untuk mengukur tingkat pemahaman dan penguasaan materi selama pelatihan. Kemudian dilanjutkan dengan evaluasi dan monitoring (Mardin et al., 2019).

\section{Tahap Evaluasi dan Monitoring}

Evaluasi digunakan untuk mengukur tingkat keberhasilan pelatihan yang dilakukan (Parmadi \& Widodo, 2021). Evaluasi diberikan melalui pretest dan 
posttest nilai hasil ujian pelatihan keterampilan akuntansi berbasis SAK-ETAP. Selain itu, pengukuran kepuasan peserta digunakan sebagai indikator keberhasilan capaian selama kegiatan berlangsung (Diyanah et al., 2019).

\section{PEMBAHASAN}

\section{Tahap Perencanaan}

Tim dosen (instruktur) akuntansi UIN Sunan Ampel Surabaya menyusun modul pelatihan yang berisi materi dan berbagai bentuk kasus akuntansi dari rujukan terbaru, serta penyelesaian yang aplikatif untuk memudahkan peserta memahami tanpa adanya tutorial (Hermawan et al., 2021). Selain itu, materi pretest dan posttest juga disiapkan sebagai bahan evaluasi dan monitoring selama pelaksanaan kegiatan berlangsung.

\section{Tahap Pelaksanaan}

Peserta penguatan kapasitas keterampilan akuntansi adalah siswa SMK 2 Antartika, Sidoarjo yang berjumlah 147 orang. Peserta terdiri dari berbagai siswa yang memiliki keterampilan dasar penguasaan akuntansi jasa, akuntansi dagang, dan akuntansi manufaktur. Pelatihan menyasar sejumlah 6 (enam) kelas yang sudah lulus dari mata pelajaran akuntansi dasar, perpajakan, maupun dasar-dasar penyusunan laporan keuangan berbasis entitas tanpa akuntabilitas publik (SAK-ETAP).

Tabel 1. Karakteristik peserta penguatan kapasitas keterampilan akuntansi berbasis SAK-ETAP

\begin{tabular}{llcr}
\hline Peserta & & Frequency & Percent \\
\hline Jenis Kelamin & Laki-laki & 20 & 13.6 \\
& Perempuan & 127 & 86.4 \\
Kelas & Total & 147 & 100.0 \\
& Akuntansi A & 33 & 22.4 \\
& Akuntansi B & 19 & 12.9 \\
& Akuntansi C & 29 & 19.7 \\
& Akuntansi D & 25 & 17.0 \\
& Akuntansi E & 25 & 17.0 \\
Keterampilan & 16 & 10.9 \\
Dasar & Akuntansi F & 147 & 100.0 \\
& Total & 58 & 38.5 \\
& Jasa & 44 & 29.9 \\
& Dagang & 45 & 30.6 \\
& Manufaktur & 147 & 100.0 \\
\hline
\end{tabular}

Sebagian besar peserta didominasi oleh perempuan sebanyak 127 (86.4\%) dari 147 peserta yang mengikuti. Sementara peserta tersebar di 6 (enam) kelas. Pada saat pelatihan dilakukan pengacakan kelas, sehingga peserta tidak bisa melakukan kecurangan selama proses pelatihan maupun ujian keterampilan berlangsung. Selain itu, para peserta dibekali keterampilan dasar sebagai pemetaan pelatihan keterampilan akuntansi yang yang menunjukkan bahwa sebesar $38.5 \%$ peserta sangat menguasai keterampilan akuntansi jasa, $29.9 \%$ peserta sangat menguasai keterampilan akuntansi dagang, dan 30,6\% peserta sangat menguasai keterampilan akuntansi manufaktur (Tabel 1).

Diskusi sebelum kegiatan penguatan kapasitas keterampilan akuntansi berbasis SAK-ETAP memberikan informasi untuk memetakan kebutuhan materi yang menjadi pembahasan selama kegiatan berlangsung. Selain diskusi awal, dilakukan kegiatan pretest kepada para peserta terkait pembahasan keterampilan akuntansi berbasis SAK-ETAP (Gambar 2).

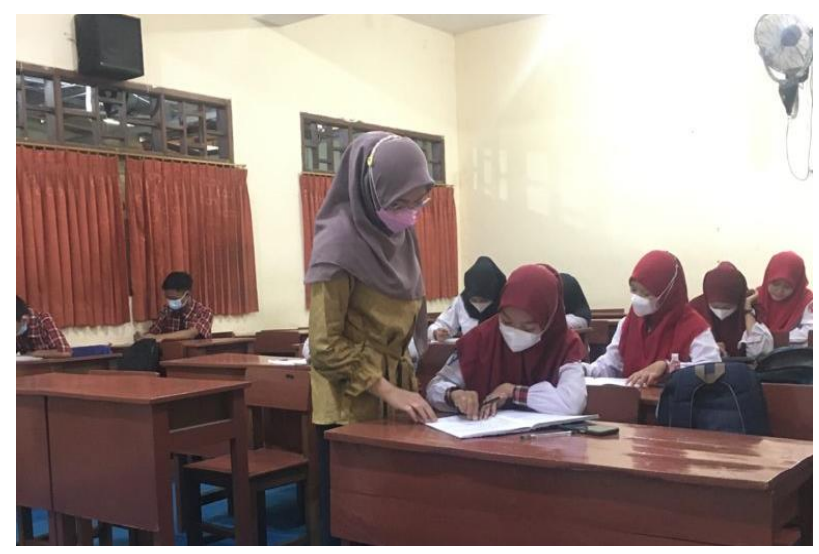

Gambar 2. Pendampingan pretest ujian

\section{Tahapan Evaluasi dan Monitoring}

Evaluasi dan monitoring dilakukan secara terstruktur dan sistematis oleh setiap instruktur (dosen) kepada peserta penguatan kapasitas keterampilan akuntansi berbasis SAK-ETAP. Indikator keberhasilan kegiatan ini ditentukan oleh peningkatan nilai hasil ujian sebelum dan sesudah materi yang diberikan oleh setiap instruktur. Analisis data menggunakan wilcoxon signed rank test sebagai pengujian hipotesis. Tingkat ketercapaian dan pemahaman diukur dari tingkat kepuasan peserta selama kegiatan keterampilan akuntansi berbasis SAK-ETAP berlangsung. Berdasarkan Tabel 2 menunjukkan adanya perbedaan kemampuan rata-rata sebelum dan sesudah materi yang diberikan oleh setiap instruktur kegiatan.

Peningkatan kapasitas peserta dalam menyelesaikan kasus akuntansi berbasis SAK-ETAP disebabkan adanya refreshment yang dilakukan oleh setiap instruktur kelas tentang materi dasar hingga lanjutan (Gambar 3). Senada dengan Murniasih \& Ferdiani (2018) yang menjelaskan bahwa siswa memerlukan upaya refreshment dari guru melalui desain pembelajaran yang menarik dengan berbagai media yang dapat dimanfaatkan. Setiap instruktur (tim 
dosen) juga memberikan contoh kasus aplikatif dengan bahasa sederhana yang dapat ditangkap dengan mudah oleh peserta dengan level pendidikan sekolah menengah atas. Selain itu, pendampingan dilakukan sesuai dengan tahapan alur siklus akuntansi berbasis SAK-ETAP yang memenuhi ketercapaian penyusunan laporan keuangan secara handal dan relevan.

Tabel 2. Hasil pretest dan posttest

\begin{tabular}{cccc}
\hline Wilcoxon Signed Ranks Test & N & $\begin{array}{c}\text { Mean } \\
\text { Rank }\end{array}$ & $\begin{array}{c}\text { Sum of } \\
\text { Ranks }\end{array}$ \\
\hline Posttest -Negative Ranks & $13^{a}$ & 48.31 & 628.00 \\
Pretest Positive Ranks & $126^{b}$ & 72.24 & 9102.00 \\
Ties & $8^{c}$ & & \\
Total & 147 & & \\
Z & -8.917 & & \\
Asymp. Sig & $(2-.000$ & & \\
tailed) & & & \\
\hline
\end{tabular}

aposttest < Pretest

bposttest > Pretest

cPosttest $=$ Pretest

\section{Kemampuan Menyelesaikan Kasus}

Akuntansi berbasis SAK-ETAP

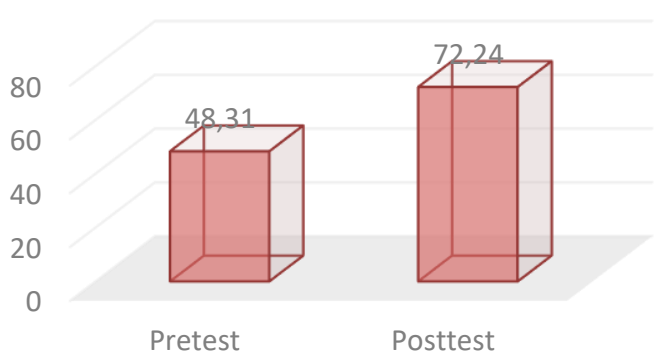

Gambar 3. Peningkatan kapasitas peserta dalam menyelesaikan kasus akuntansi berbasis SAK-ETAP

Peserta merasakan kecukupan dan kepuasan pada materi yang telah diberikan selama kegiatan pelatihan berlangsung. Berdasarkan Gambar 4, dapat dilihat bahwa hampir setengah lebih atau sebesar $83 \% \quad(70 \%$ Sangat memuaskan \& $13 \%$ Memuaskan) peserta merasakan kepuasan atas kegiatan pengabdian yang dilakukan oleh dosen akuntansi Universitas Islam Negeri Sunan Ampel Surabaya. Tingkat kepuasan peserta terhadap kegiatan pengabdian ini menunjukkan bukti bahwa proses pendampingan dari awal hingga evaluasi akan pentingnya keterampilan akuntansi berbasis SAK-ETAP di dunia kerja sangat dibutuhkan. Salamah et al. (2019) menjelaskan bahwa pengembangan profesi dilakukan untuk menjaga dan meningkatkan kualitas kinerja profesi agar semakin profesional dalam melaksanakan tugasnya.

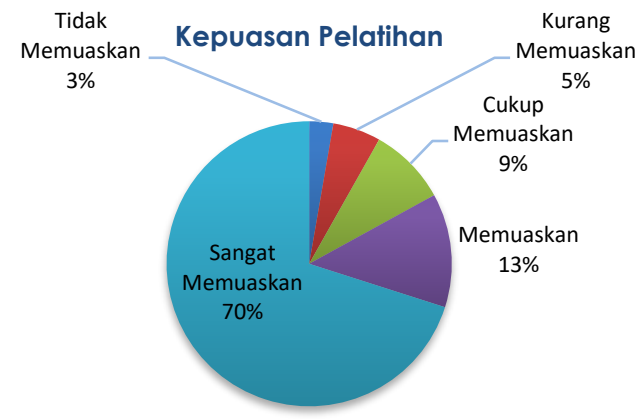

Gambar 4. Tingkat Kepuasan Peserta terhadap Kegiatan Pengabdian

Tidak hanya tentang pengalaman, namun skill ketepatan dan kecepatan menyelesaikan suatu persoalan di dunia kerja menjadi pertimbangan pimpinan/manajemen dalam akselerasi karir karyawan di ruang lingkup pekerjaan tertentu, terutama pada karier profesi seperti seorang akuntan, baik akuntan manajemen, akuntan keuangan, akuntan pajak, (Nawangsari et al., 2020) dan lain sebagainya.

\section{KESIMPULAN}

Berdasarkan hasil pelatihan dan pembahasan dapat disimpulkan bahwa terdapat perbedaan yang signifikan hasil pretest dan posttest nilai hasil ujian keterampilan akuntansi berbasis SAK-ETAP oleh peserta SMK Antartika 2 Sidoarjo. Hasil ini menunjukkan bahwa adanya kesiapan peserta didik (siswasiswi) SMK Antartika 2 Sidoarjo dalam menghadapi dunia kerja pasca kelulusan. Tingkat kepuasan sebesar $83 \%$ menunjukkan adanya keseriusan dan tanggungjawab pengabdian dosen akuntansi UIN Sunan Ampel Surabaya, yang dapat dilihat dari komitmen dan kinerja yang baik. Kurangnya konsistensi kehadiran peserta selama pelatihan menjadi hambatan dari pengabdian ini.

Kegiatan pengabdian ini memiliki pelvang bagi sekolah-sekolah yang berbasis kejuruan dan terapan seperti jurusan akuntansi. Selain itu, perkembangan akuntansi terutama pada penguasaan teknik akuntansi dapat menjadi kesempatan bagi penelitian berbasis pengabdian masyarakat, dan diharapkan penelitian berbasis pengabdian masyarakat bisa dilakukan pada bidang teknik akuntansi lain seperti akuntansi manajemen, akuntansi perpajakan, akuntansi pemerintahan dan akuntansi pesantren di masa yang akan datang dikarenakan saat ini keahlian di bidang tersebut sangat dibutuhkan dalam dunia kerja profesional maupun aktivitas sosial kemasyarakatan misalnya pada lembaga sosial masyarakat yang merupakan bagian dari non profit organization. 


\section{UCAPAN TERIMA KASIH}

Penulis mengucapkan terima kasih kepada Universitas Islam Negeri Sunan Ampel Surabaya, SMK 2 Antartika Sidoarjo. dan semua pihak yang membantu pelaksanaan pengabdian masyarakat ini.

\section{DAFTAR PUSTAKA}

Anggapraja, I. T. (2016). Pengaruh Penerapan Knowledge Management dan Pengembangan Sumber Daya Manusia terhadap Kinerja Karyawan PT Telkom Tbk. (Studi Explanatory Survey pada Karyawan Unit Human Capital Management PT Telkom Tbk.). Jurnal Aplikasi Manajemen, 14(1), 140-146. https://doi.org/10.18202/jam23026332.14.1.15

Bahfiarti, T., Arianto, A., Fatimah, J. M., \& Farid, M. (2020). Literasi Multikultural Komunitas Etnik Kampung Rama Kecamatan Panakukang Kota Makassar. Jurnal Pengabdian Kepada Masyarakat, 26(2), 55-59. https://doi.org/10.24114/jpkm.v26i2.17150

Diyanah, K. C., Pawitra, A. S., Ati, L. P. A. P., Bastian, M., Septyaningsih, I., \& Prasetyo, R. A. (2019). Pendampingan Masyarakat Bantaran Sungai dalam Pendirian Bank Sampah untuk Meminimalisir Sampah Sungai di Kelurahan Pegirian Kota Surabaya. Engagement: Jurnal Pengabdian Kepada Masyarakat, 3(2), 245-261. https://doi.org/10.29062/engagement.v3i2.32

Hermawan, S., Hanun, N. R., \& Junjunan, M. I. (2021). ELearning and Understanding of Accounting During Covid-19 Pandemic. International Journal of Social Science and Business, 5(1), 44-51. https://doi.org/10.23887/ijssb.v5i1.30917

Junjunan, M. I., Asegaf, M. M., \& Takwil, M. (2020). Pengaruh Transparansi, Akuntabilitas, dan IGCG terhadap Tingkat Kepercayaan Muzakki di Lembaga Amil Zakat Dompet Amanah Umat. Akuntansi: Jurnal Akuntansi Integratif, 6(2),

$112-125$. https://doi.org/10.29080/jai.v6i2.289

Junjunan, M. I., Nawangsari, A. T., \& Hanun, N. R. (2021). New Normal: Learning from Home, the Availability of Information Technology and e-Learning Implementation as a Determinant of Accounting Students' Understanding. JIA (Jurnal IImiah Akuntansi), 6(1), https://doi.org/10.23887/jia.v6i1.30897

Lukman, H., \& Juniati, C. (2016). Faktor Yang Pengaruhi Pemilihan Karir Sebagai Akuntan Publik Bagi Mahasiswa Pts Wasta Dengan Pendekatan Reasoned Action Model. Jurnal Akuntansi, 20(2), 202215. https://doi.org/10.24912/ja.v20i2.54

Mahardika, D. P. K. (2020). Meninjau Peran Akuntan dalam Menanggulangi Isu Perubahan Iklim. Jurnal Akuntansi Multiparadigma, $11(3)$, 581-599. https://doi.org/10.21776/ub.jamal.2020.11.3.33

Mardin, M., Arif, A., \& Ahmad, F. (2019). Pengolahan Buah Naga Kelompok Bulo (Badan Usaha Lorong) Teratai
Putih. CARADDE: Jurnal Pengabdian Kepada Masyarakat, 2(1), 105-112. https://doi.org/10.31960/caradde.v2i1.240

Murniasih, T. R., \& Ferdiani, R. D. (2018). Pelatihan Smart Diagram Venn Pada Materi Himpunan SMP. Aksiologiya: Jurnal Pengabdian Kepada Masyarakat, 2(2), 125-130. https://doi.org/10.30651/aks.v2i2.1246

Nawangsari, A. T., Junjunan, M. I., \& Mulyono, R. D. A. P. (2020). Sustainability Reporting: Sebuah Analisis Bibliometrik Pada Database Scopus. Journal of Applied Accounting and Taxation, 5(2), 137-157. https://doi.org/10.30871/jaat.v5i2.2182

Nugraheni, P., Indrasari, A., Hamzah, N., \& Maelah, R. (2020). Managing social and environmental activities: toward sustainability of companies. Jurnal Akuntansi dan Auditing Indonesia, 24(2), 130-138. https://doi.org/10.20885/jaai.vol24.iss2.art6

Parmadi, E. H., \& Widodo, Y. H. (2021). Pemberdayaan lbu PKK Desa Bleberan Melalui Pelatihan Kewirausahaan dalam Upaya Mendukung Desa Wisata Bleberan. Wikrama Parahita: Jurnal Pengabdian Masyarakat, 5(2), $114-118$. https://doi.org/10.30656/jpmwp.v5i2.2797

Purnama, D., Punwanto, B., \& Irwanto, A. K. (2018). Strategi Peningkatan Kinerja Perusahaan Berdasarkan Keunggulan Kompetitif yang Berkelanjutan dan Perencanaan Sumber Daya. Jurnal Manajemen dan Organisasi, 9(1), https://doi.org/10.29244/jmo.v1i1.25337

Rosyadi, S., Setyoko, P. I., Kurniasih, D., Ramadhanti, W., Kusuma, A. S., \& Atika, Z. R. (2021). Penguatan Kapasitas Peran Sosial Bumdes dalam Penanggulangan Dampak Ekonomi COVID19. Wikrama Parahita: Jurnal Pengabdian Masyarakat, 5(1), 27-32. https://doi.org/10.30656/jpmwp.v5i 1.2554

Salamah, I., Lindawati, L., Asriyadi, A., \& Kusumanto, R. D. (2019). Peningkatan kemampuan guru-guru SD negeri 130 Palembang dalam menyajikan presentasi atraktif melalui pelatihan Microsoft Power Point. Aksiologiya: Jurnal Pengabdian Kepada Masyarakat, 4(1), 52-62. https://doi.org/10.30651/aks.v4i1.2197

Syahril, S., \& Andini, I. Y. (2017). The role of accountants in implementation corporate social responsibility at Hospital Dr. H. Moh. Anwar Sumenep District. JEMA: Jurnal Ilmiah Bidang Akuntansi dan Manajemen, 14(2), 120-134. https://doi.org/10.31 106/jema.v14i02.509

Zaitul, Puttri, D., Novianti, N., \& llona, D. (2020). Accounting Standard, Corporate governance, and accounting quality. Accounting Standard, Corporate governance, and accounting quality, 12 (2), 404-415. https://ejournal.upi.edu/index.php/aset/article/view /28698 